\title{
Serum thymic hormone activity in genetically-obese mice
}

\author{
BY R. K. CHANDRA, GLORIA HERESI AND B. AU \\ Department of Pediatrics, Memorial University of Newfoundland, St John's, \\ Newfoundland, Canada and Department of Nutrition and Food Science, Massachusetts \\ Institute of Technology, Cambridge, Massachusetts, USA
}

(Received 7 May 1980 - Accepted 9 September 1980)

1. Serum thymic hormone was assayed in genetically-obese (C57B1/6J ob/ob) mice and lean controls $(+/+$, $+/-)$ of the same strain.

2. The thymic hormone activity was higher in the majority of the obese animals compared with non-obese mice.

3. The number of antibody-forming cells in the spleen expressed as a proportion of the total mononuclear cells was increased in the obese mice.

4. It is suggested that obesity is associated with significant changes in the thymic hormone levels which may alter the relative proportion of lymphocyte subsets and cell-mediated immunity.

Nutritional modulation of immune responses is a critical determinant of morbidity in many clinical disorders. Protein-energy malnutrition and deficiencies of specific nutrients impair immunocompetence in man and experimental animals (Chandra \& Newberne, 1977; Suskind, 1977; Chandra, 1980a). The effects of overnutrition and obesity on immunity functions are largely unknown. Limited information suggests that overfeeding increases susceptibility to infection (Newberne, 1966; Fiser et al. 1975). We have examined thymic function in genetically-obese mice and found changes in serum thymic hormone activity and antibody-forming cell response.

\section{MATERIALS AND METHODS}

Animals. C57B1/6J obese $(o b / o b)$ and lean $(+/+,+/-)$ mice were obtained at the age of 8-10 weeks from Jackson Laboratory, Bar Harbor, Maine. The animals were housed in individual cages in a room maintained automatically at $21^{\circ}, 40-50 \%$ humidity, and $12 \mathrm{~h}$ alternating periods of light and dark. Regular laboratory diet was provided ad lib. On average, the obese group consumed $75 \%$ more food than controls.

Thymic hormone activity. Serum thymic hormone activity was assayed by the method of Bach \& Dardenne (1973). The blood was allowed to clot at $4^{\circ}$ in plastic centrifuge-tubes. The serum was separated in a refrigerated centrifuge and ultrafiltered immediately.

Thymic factor activity was assayed on the same day that the blood was collected. Spleen cells were obtained from 8-12-week-old male C57B1/6J mice that had been thymectomized 10-20 d before they were killed. The cells were dissociated, washed twice in Hanks solution, resuspended in a concentration of $30 \times 10^{\circ} \mathrm{cells} / \mathrm{ml}$, and incubated at $37^{\circ}$ with serial $\log _{2}$ dilutions of test sera in Hanks medium containing azathioprine $(10 \mu \mathrm{g} / \mathrm{ml})$. After $80 \mathrm{~min}$, a suspension $(10 \mathrm{ml} / \mathrm{l})$ of sheep erythrocytes (SRBC) was added. SRBC had been kept in Alsevier's solution for up to 3 weeks and before use were washed twice with saline and twice with Hanks solution. The cell suspension was centrifuged at $4^{\circ}$ for $5 \mathrm{~min}$ and resuspended gently. Rosettes were observed in a haemocytometer. The highest dilution of test serum sample which was able to restore azathioprine sensitivity, i.e. induce $50 \%$ inhibition of SRBC rosette-forming cells, was taken as the titre of thymic factor activity in the serum. 
Antibody-forming cells. Obese and control mice were immunized intraperitoneally with $2 \times 10^{8} \mathrm{SRBC}$ and killed $10 \mathrm{~d}$ later to estimate the number of antibody haemolytic plaque-forming cells (PFC) in the spleen (Dressor \& Wortis, 1966).

Statistics. Statistical analysis used Student's $t$ test.

\section{RESULTS AND DISCUSSION}

The titre of thymic factor activity in the sera of genetically-obese mice was higher than the lean controls of the same strain (Fig. 1). The difference between the mean values was statistically significant $(P<0 \cdot 01)$. Similarly, the PFC response was higher in the obese mice (Table 1). This type of immune response to heterologous erythrocytes requires the balanced co-operation of thymic-dependent T lymphocytes, both 'helper' and 'suppressor', antibodyforming B lymphocytes and macrophages (Miller, 1972). In animals with primary or secondary defects of thymic function, e.g. athymic nude $n u / n u$ mice, neonatallythymectomized and nutritionally-deprived animals, the PFC response is reduced, as are levels of serum thymic hormone activity (Brent \& Holborow, 1974; Chandra, 1975, 1979; van Bekkum, 1975; Goldstein, 1977; Heresi \& Chandra, 1980). Thymic microenvironment or soluble factors ('hormones') produced by the thymus or both play a critical role in the differentiation, maturation and function of T cells. The higher PFC response in the obese animal may be causally linked to increased thymic hormone activity. Alternatively, it may be the result of changes in lymphocyte subpopulations, and increase in 'helper' cells or a decrease in 'suppressor' cells. It is also possible that the thymic hormone levels are controlled by a genetic locus very closely linked with the $o b$ gene but otherwise completely unrelated.

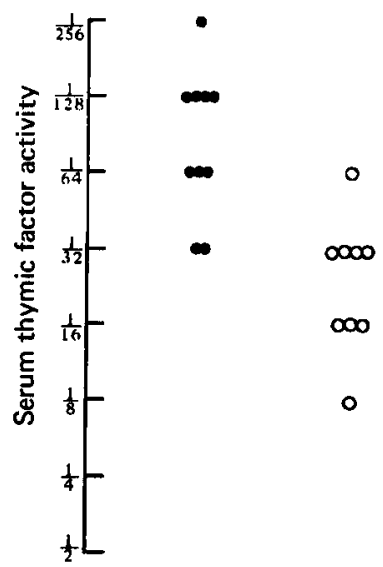

Fig. 1. Serum thymic factor activity in genetically-obese mice $(O)$ and lean controls $(O)$.

Table 1. Plaque-forming cell (PFC) response in genetically-obese and lean mice. (Mean values with their standard error for nine mice/group)

\begin{tabular}{|c|c|c|}
\hline & $\begin{array}{c}\text { IgM PFC } \\
\text { (1106 spleen } \\
\text { cells) }\end{array}$ & $\begin{array}{c}\text { IgG PFC } \\
\text { (/106 spleen } \\
\text { cells) }\end{array}$ \\
\hline $\begin{array}{l}\text { Obese } \\
\text { Lean } \\
\text { Statistical significance } \\
\text { of difference: } P\end{array}$ & $\begin{array}{c}401 \pm 43 \\
296 \pm 27 \\
<0.01\end{array}$ & $\begin{array}{c}439 \pm 51 \\
348 \pm 37 \\
<0.05\end{array}$ \\
\hline
\end{tabular}


The pathogenesis of altered immunologic responses in obesity is not known. Inherited obesity caused by the recessive $o b$ gene is associated with many metabolic, nutritional and hormonal changes (Herberg \& Coleman, 1977). Recent results suggest that such changes may be important determinants of altered immune responses in the obese. For example, it has been reported that the cytotoxic response of spleen cells of obese mice immunized in vivo with tumor cells is markedly reduced compared with lean controls, whereas the same response after in vitro sensitization was unimpaired (Meade et al. 1979; Chandra, 1980b; Chandra \& $\mathrm{Au}, 1980)$. The apparent conflict in the results of PFC response and cytotoxic activity of spleen cells may be explained by the heterogeneity of lymphocyte subpopulations involved in these phenomena. Such differences related to mode of immunization point to the presence of a deleterious microenvironment (increased levels of insulin, adrenocorticotrophic hormone, glucose, lipid, etc.) in the genetically-obese mice. The mechanism(s) by which obesity-associated metabolic and endocrine changes influence thymic hormone activity and immune responses is not known. Further studies clarifying these interactions are in progress.

The study was supported by a grant from the Faculty of Medicine Research Development Fund.

\section{REFERENCES}

Bach, J. F. \& Dardenne, M. (1973). Immunology 25, 353.

Brent, L. \& Holborow, J. (eds.) (1974). Prog. Immun. 2.

Chandra, R. K. (1975). Science, N.Y. 190, 289.

Chandra, R. K. (1979). Clin. exp. Immun. 38, 228.

Chandra, R. K. (1980a). Immunology of Nutritional Disorders. London: Edward Arnold.

Chandra, R. K. (1980b). Am. J. clin. Nutr. 33, 13.

Chandra, R. K., \& Au, B. (1980). Int. Arch. Allergy Appl. Immunol. 61, 94.

Chandra, R. K., \& Newberne, P. M. (1977). Nutrition, Immunity and Infection: Mechanisms of Interactions. New York: Plenum.

Dressor, D. W. \& Wortis, H. H. (1966). Nature, Lond. 208, 859.

Fiser, R. H., Rollins, J. B. \& Biesel, W. R. (1975). Am. J. vet. Res. 33, 713.

Goldstein, G. (1977). In Progress in Immunology, vol. 3, p. 390 [T. E. Mandel, C. Cheers and C. S. Hosking, editors]. New York: Elsevier.

Herberg, L. \& Coleman, D. L. (1977). Metabolism 26, 59.

Heresi, G. \& Chandra, R. K. (1980). J. Nutr. (In the Press).

Meade, C. J., Sheena, J. \& Mertin, J. (1979). Int. Arch. Allergy Appl. Immunol. 58, 121.

Miller, J. F. A. P. (1972). Int. Rev. Cytol. 33, 77.

Newberne, P. M. (1966). Fedn Proc. Fedn Am. Socs exp. Biol. 25, 1701.

Suskind, R. M. (ed.) (1977). Malnutrition and the Immune Response. New York: Raven.

van Bekkum, D. W. (ed.) (1975). The Biological Activity of Thymic Hormones. Rotterdam: Kooyker. 